\title{
Essential Oil of Mustard to Control Rhizoctonia solani Causing Seedling Damping off and Seedling Blight in Nursery
}

\author{
Onkar D. Dhingra, Maria L. N. Costa, Geraldo J. Silva, Jr. \& Eduardo S. G. Mizubuti \\ Departamento de Fitopatologia, Universidade Federal de Viçosa, CEP 36570-000, Viçosa, MG, Brazil, \\ fax: (31) 3899-2240, e-mail: dhingra@ufv.br \\ (accepted for publication 08/07/2004)
}

Corresponding Author: Onkar D. Dhingra

DHINGRA, O.D., COSTA, M.L.N., SILVA, JR. G.J, \& MIZUBUTI, E.S.G. Essential oil of mustard to control Rhizoctona solani seedling damping off and seedling blight in nursery. Fitopatologia brasileira 29:683-686. 2004.

\begin{abstract}
The essential oil extracted from mustard (Brassica rapa) seeds was evaluated for its effect on suppression of Rhizoctonia solani growth in vitro, and in field soils, for reducing saprophytic substrate colonization and seedling damping off and blight using snap beans as indicator plant, the in vitro growth was completely inhibited at a concentration of $50 \mu \mathrm{l} / \mathrm{l}$. The saprophytic substrate colonization in soils $24 \mathrm{~h}$ after treatment was drastically reduced to $45 \%$ at $150 \mu \mathrm{l} / \mathrm{kg}$ soil concentration, in contrast to $100 \%$ colonization at concentrations of 0,50 , or $75 \mu 1 / \mathrm{kg}$. This recovery rate gradually declined to $6 \%$ and $60 \%$, respectively, in nine days.

A control of pre and post-emergence seedling damping off and blight in common beans (Phaseolus vulgaris), without any apparent phytotoxic effect was achieved by irrigating $R$. solani infested soils with water containing the emulsified essential oil to provide 150 $\mu 1 / 1$ soil volume ten days prior to planting, gave over $95 \%$. The effect of the mustard essential oil was not influenced by the physical soil texture, and it appears to be a good substitute for methyl bromide fumigation in nurseries for seedling production.

Additional keywords: allyl isothiocyanate, flavoring agent, soil treatment, nursery.
\end{abstract}

\section{RESUMO}

Utilização de óleo essencial de mostarda no controle de tombamento e requeima causadas por Rhizoctonia solani em viveiro

Foi avaliado o efeito do óleo essencial extraído de sementes de mostarda (Brassica rapa) na supressão do crescimento in vitro de Rhizoctonia solani, na redução da colonização saprofítica no solo, e no tombamento e requeima de plântulas, utilizando feijão-vagem (Phaseolus vulgaris) como planta indicadora. $\mathrm{O}$ crescimento in vitro de $R$. solani foi completamente inibido na concentração de $50 \mu \mathrm{l} / 1$. A colonização saprofítica do substrato foi drasticamente reduzida para
$45 \%$ na concentração de $150 \mu \mathrm{l} / \mathrm{kg}, 24 \mathrm{~h}$ após o tratamento. Nas concentrações de 0,50 e $75 \mu \mathrm{l} / \mathrm{kg}$ de solo houve $100 \%$ de colonização do substrato. Esta taxa de recuperação diminuiu gradualmente para $6 \%$ e $60 \%$, respectivamente, em nove dias. A irrigação de solos infestados por $R$. solani com água contendo o óleo essencial emulsificado para fornecer $150 \mu \mathrm{l} / \mathrm{l}$ de solo, dez dias antes do plantio, resultou em $95 \%$ de controle do tombamento e requeima em mudas de feijão-vagem, sem qualquer efeito aparente de fitotoxidez. O efeito do óleo essencial não foi influenciado pela textura do solo e parece ser um bom substituto para o fumigante brometo de metila em viveiros.
The losses caused by the Rhizoctonia solani Kühn in seedling production of transplant perennial [eucalyptus (Eucalyptus spp,), coffee (Coffea arabica L.), etc.] or vegetable crops [cabbage (Brassica oleracea L.), tomato (Lycopersicon esculentum Mill.), pepper (Capsicum spp.), etc.] are high in nurseries as well as in the field when asymptomatically infected seedlings are transplanted. Generally, $R$. solani is eradicated from the seedling substrate by fumigation with methyl bromide. This highly toxic fumigant that also damages the ozone layer is being gradually prohibited throughout the world. In Brazil its use has been restricted to specific purposes; beginning December 2006 it will be prohibited for use in nurseries (MAPA, 2002). However, there is no efficient substitute available for nursery use at this time.

Several studies have shown that amending the soil with plants of Brassica spp. can reduce the disease incidence or inoculum level of Macrophomina phaseolina (Tassi) Goid., Pythium ultimum Trow., Fusarium oxysporum Schl. f. sp. cumini Patel, Prasad \& Mathur and R. solani (Charron \& Sams 1999, Mawar \& Lodha, 2002, Lodha \& Sharma, 2002). Seed treatment with Brassica spp. seed meal to control $R$. solani in cabbage has been reported (Chung et al., 2002). The mechanism involved in the disease control or suppression of a pathogen is considered to be the production of allyl isothiocyanate (AITC) by the tissues of Brassica spp. (Olivier et al., 1999). Antimicrobial activity of AITC is well documented in the literature, and it can kill fungal propagules by vapor action, thus acting as a fumigant (Lin et al., 2000, Nielsen \& Rios, 2000; Mari et al., 2002). This volatile compound is produced in an aqueous medium through enzymatic hydrolysis of sinigrin, which is the predominant glucosinolate in the tissues of Brassica spp. Among the Brassica spp. the highest concentrations of AITC are found in some mustered (Brassica juncea L.), horseradish [Armoraracia (Gaertn.) Mey. \& Scherb] and wasabi (Wasabia japonica Matsum) species, with considerable variation among 
O.D. Dhingra et al.

the cultivars of the same species (Olivier et al.,1999).

Although soil amendments with fresh mustard leaves or seed meal have shown promising results for controlling soil born pathogens, results can be inconsistent due to variations in AITC content. The use of fresh plant materials is unsuitable in the nursery because there is no practical method for standardizing their processing and the materials are not readily available. Also, there is no information regarding the fate of AITC during storage and the factors that influence its production in amended soil. These restraints can lead to inconsistency of disease control. A ready to use, standardized product is more desirable in nurseries to ensure consistent control of soil borne $R$. solani. The AITC rich essential oil can be extracted from seeds or other plant tissues. This essential oil is widely used as a flavoring agent by the food industry and is classified as generally regarded as safe (GRAS) by the Food and Drug Administration of the United States. Therefore, the following exploratory study was done to determine the feasibility of using the mustard essential oil for soil treatment to control $R$. solani inoculum in a substrate for seedling production.

The essential oil was extracted from mustard seeds using the following procedure. Five kilogram of mustard seeds were ground to pass through a $0.5 \mathrm{~mm}$ screen and soaked in 101 of water. The mixture was allowed to stand for $4 \mathrm{~h}$ at room temperature for hydrolysation of glucosinolates and then hydrodistilled using a stationary distillator at $100{ }^{\circ} \mathrm{C}$ and air flow of $5 \mathrm{l} / \mathrm{min}$. The distillate containing water and the essential oil was collected into several separatory funnels, and allowed to stand for $2 \mathrm{~h}$ to separate the oil from the water phase. The water phase was discarded and the collected essential oil was dehydrated by passing through a $5-\mathrm{cm}$ column of anhydride sodium sulfate. It was then emulsified with $10 \%$ Tween ${ }^{\circledR} 20$ and refrigerated until use.

The $R$. solani isolate used in this study was obtained from snap bean (Phaseolus vulgaris L.) seedlings collected from a commercial vegetable field having a history of extensive damage caused by the fungus. After isolation, the pathogenicity of the isolate was tested by placing a three-day old potato-dextrose agar (PDA) culture disc on the soil surface close to the collar region of snap bean seedlings growing in pots containing methyl bromide treated soil. The collar rot symptoms developed within four days and the fungus was reisolated from the diseased portion of the seedlings, and the stock culture was stored over silica gel for further use. All new cultures of the fungus were started using this stock culture, avoiding repeated sub-culturing on artificial culture media. The $R$. solani inoculum for soil infestation was produced on autoclaved snap bean pods, dried and ground to $1 \mathrm{~mm}$ mesh (Dhingra \& Sinclair, 1995).

To determine the effect of the mustard essential oil on in vitro growth of $R$. solani, the fungus was cultivated on PDA containing the essential oil at concentrations of 0,10 , $25,50,75$ or $150 \mu 1 / 1$. The emulsified oil was thoroughly mixed with $60-\mathrm{ml}$ cool molten PDA, and the mixture was poured into five $9-\mathrm{cm}$ culture plates. The medium in each culture plate was seeded with a 5-mm culture disc obtained from the advancing margin of $R$. solani colony growing on water agar, and incubated at $25{ }^{\circ} \mathrm{C}$. The fungal growth was observed daily for 15 days, although in the control plates the fungus had reached the margins in four days.

To study the effect of the essential oil on the saprophytic activity of $R$. solani in soil, three soils of different textures were used. The soils were characterized as sandy-loam (65\% sand, $22 \%$ silt, and $13 \%$ clay, water holding capacity (WHC) $32 \%$ ), silty-clay loam ( $25 \%$ sand, $44 \%$ silt $31 \%$ clay, WHC $54 \%$ ), and sandy clay loam (69\% sand, $7 \%$ silt, $24 \%$ clay, WHC $42 \%$ ). The soils were collected from three different fields of vegetable production, with histories of $R$. solani damage to vegetable crops. The soils were air-dried, sieved through $1.5 \mathrm{~mm}$ sieve, and the inoculum of $R$. solani was augmented by mixing the dry inoculum $(5 \mathrm{~g} / \mathrm{kg}$ soil $)$ in a twin arm mixer.

The soils were treated with the essential oil at concentrations of $0,50,75$, and $150 \mu 1 / \mathrm{kg}$ dry soil. A $250 \mathrm{~g}$ portion of each soil was placed in an appropriate plastic bowl, emulsified essential oil mixed with enough water to moisten the soil to 50\% WHC was added and thoroughly blended with an electric blender. The saprophytic activity was determined through colonization of snap bean petiole segments. Petioles were collected from lower leaves of six-week old snap bean plants, and were cut into $1-\mathrm{cm}$ long segments, boiled for 2 min, blot-dried, and 20 of them were mixed with the soil. The mixture was then tap-packed in 250-ml beakers, which were then covered with a polyethylene film and incubated at $25^{\circ} \mathrm{C}$. The petiole segments were recovered from soil, by wet sieving, one, three, six, and nine days after incubation. There was a separate beaker for each sampling date. The recovered segments were washed under running tap water with gentle scrubbing with a soft brush to remove the closely adhered soil particles, blot-dried, surface disinfested by dipping in $70 \%$ ethanol for $1 \mathrm{~min}$ and then plated on the selective medium (Ko \& Hora, 1971, 1995). The segments yielding $R$. solani were counted after an incubation of three days at $25^{\circ} \mathrm{C}$.

The capacity of the essential oil of mustard to control $R$. solani seedling blight and damping off was studied using sandy-loam and silty-clay-loam soil with augmented inoculum as described earlier. The soil was distributed into perforated plastic trays ( $50 \mathrm{~L} \times 25 \mathrm{~W} \times 30 \mathrm{D} \mathrm{cm})$ to a depth of $25 \mathrm{~cm}$ and irrigated to full WHC and 50 snap bean seeds were planted in each tray to determine the uniformity of disease incidence. The seedlings with $R$. solani symptoms were counted at the fully expanded primary leaf stage and then discarded.

The soil in each tray was then treated with the essential oil at the rate of $150 \mu 1 / 1$ soil volume by irrigating with 21 of water containing the required amount of the essential oil. Soil irrigated with water only served as control. Ten days after the treatment 30 snap bean seeds were planted in each tray. No further treatment was given except irrigation as required. The number of emerged seedlings and seedlings with $R$. solani symptoms was counted 25 days after seedling emergence. Isolations were made from five to ten, randomly 
Mustered essential oil to control Rhizoctonia solani seedling dampong off...

picked diseased seedlings to confirm the identity of the causal agent.

All the experiments were done in a completely randomized block design with three replications and repeated twice. After analysis of variance, the means were compared by least significant difference (LSD).

The colonies of $R$. solani in control plates reached the plate margins $(9-\mathrm{cm})$ in four days after seeding, while no growth was observed during the 15 days on the medium containing $50 \mu 1 / 1$ or higher concentrations of the essential oil. In culture plates containing 10 or $25 \mu \mathrm{l} / \mathrm{l}$, the growth was visible only after two and four days and the colony diameter reached only 5 and $3 \mathrm{~cm}$ after 15 days, respectively,.

In the saprophytic activity test in soils, the proportion of bean petioles yielding $R$. solani did not differ ( $\mathrm{p}>0.05$ ) among the soil types, independent of the treatment. Therefore the data from the three soils were pooled and reanalyzed using nine replications to determine the effect of the essential oil concentration on the saprophytic activity of $R$. solani. The proportion of bean petiole segments yielding $R$. solani was highest $24 \mathrm{~h}$ after treatment in all the treatments and started to decline thereafter. In non-treated soils or soils treated with 50 or $75 \mu 1 / \mathrm{kg}$ of the essential oil, the initial $R$. solani recovery rate of $100 \%$ declined to an average of 85,72 , and $60 \%$, three, six, and nine days after the treatment, without significant difference among the treatments and the control. But in soils treated with $150 \mu \mathrm{l} / \mathrm{kg}$ of the essential oil, the $R$. solani recovery rate was only $45,27,11$, and $6 \%$ in the corresponding sampling periods.

The total incidence of pre- and post-emergence seedling damping off and blight in snap beans, in all soil types, averaged 5\% compared to $92 \%$ in non-treated soils without significant difference among soils. There was no apparent phytotoxicity in seedlings.

In the second run of the entire study, tendency and biological significance of the treatment were similar to the first run, except for small quantitative differences in the soil tests.

The high control of snap bean seedling damping off and blight resulting from the reduction of saprophytic activity of $R$. solani as found in this initial exploratory study and the other reports (Gilardi et al., 2002, Harvey et al., 2002) strongly indicate, that the essential oil of mustard may successfully substitute methyl bromide soil fumigation to control some plant pathogens in nurseries. An in vitro toxic effect of AITC (the major component of this essential oil) on several fungi has also been reported (Lin et al., 2000; Nielson $\&$ Rios, 2000). The amount of the essential oil required to completely inhibit in vitro growth of $R$. solani and saprophytic substrate colonization differed considerably, which suggests that in vitro testing can be misleading for determinating the most effective concentration for soil treatment. The in vitro growth of $R$. solani was totally inhibited at low concentrations of $50 \mu \mathrm{l} / \mathrm{l}$ and drastically reduced even at lower concentrations of 10 or $25 \mu \mathrm{l} / \mathrm{l}$. Such magnitude of in vitro growth reduction suggests the high toxicity of mustard essential oil towards $R$. solani. But, the saprophytic growth test showed completely different results where the proportion of saprophytically colonized substrate units did not differ from the control. Even at a concentration three fold higher than the in vitro inhibitory concentration, $45 \%$ of the substrates units yielded $R$. solani, although this number declined to about $6 \%$ in nine days. These results suggest that although the fungal activity at this concentration was significantly reduced, the action was neither rapid nor as lethal as shown by the in vitro studies. The continuous decrease in fungal recovery from the substrates clearly shows fungal mortality even in the colonized substrates. On the other hand, evaluation of the real potential of mustard essential oil for soil treatment could be highly influenced by the technique used for the assay. Thus, for pathogens like $R$. solani, which have active saprophytic growth in soil, the estimation of saprophytism may provide a more realistic picture than the in vitro assays.

Rhizoctonia solani must grow saprophytically through soil prior to infecting seed or seedlings and there is a very close relationship between the two parameters (Baker \& Martinson, 1970). Since $R$. solani saprophytically colonized the substrate in treated soils, it was assumed that disease control would be inefficient if the host was planted shortly after soil treatment because the fungus would have made saprophytic growth, essential for seedling infection. The tenday wait period between the treatment and planting may explain the drastic disease control.

The data from this initial study, as well as those of others, strongly suggest that mustard essential oil has the capacity to control some the of the soil born pathogens in the nursery independent of the soil texture, thus warranting detailed and extensive research to develop it into an effective soil treatment of fungicides for substituting methyl-bromide.

\section{ACKNOWLEDGEMENT}

This research was financed by CNPq. The first, third, and the fourth author acknowledge CNPq research fellowship, and the second author thanks CAPES for scholarship.

\section{LITERATURE CITED}

BAKER, R. \& MARTINSON C.A. Epidemiology of diseases caused by Rhizoctonia solani. In: Parmeter Jr., J.R. (Ed). Rhizoctonia solani, Biology and Pathology, University of California Press, Berkeley, USA.1970. pp.172-188.

CHARRON, C.S, \& SAMS, S.E. Inhibition of Pythium ultimum and Rhizoctonia solani by shredded leaves of Brassica species. Journal American Society of Horticultural Science. 124:462-467. 1999.

CHUNG, W.C., HUANG, J.W., HUANG, H.C. \& JEN, J.F. Effect of ground Brassica seed meal on control of Rhizoctonia dampingoff of cabbage. Canadian Journal of Plant Pathology 24:211-218. 2002.

DHINGRA, O.D. \& SINCLAIR, J.B. Basic Plant Pathology Method 2nd ed. CRC Lewis Publishers, Boca Raton, Florida, USA. 1995. 
GILARDI, G, MINUTO, A., MINUTO, G. GARIBALDI, A. \& GULLINO, M.L. [Activity of natural soil fumigants against soilborne pathogens]. Colture-Protette 29:71-76. 2000.

HARVEY, S.G., HANNAHAN, H.N. \& SAMS, C.E. Indian mustard and allyl isothiocyanate inhibit Sclerotium rolfsii. Journal American Society of Horticultural Science 127:27-31. 2002.

KO, W.H., \& HORA, F.K. A selective medium for the quantitative determination of Rhizoctonia solani in soil. Phytopathology 61:707710. 1971.

LIN, C.M., PRESTON III, J.F., WEI, C.I. \& LIN, C.M. Antibacterial mechanism of allyl isothiocyanate. Journal of Food Protection 63:727-734. 2000.

LODHA, S., \& SHARMA, S.K. Effect of natural heating and Brassica amendments on survival of Macrophomina phaseolina. Indian Phytopathology 55:342-344. 2002.

MAPA. Ministério da Agricultura, pecuária e Abastecimento, Secretaria de Defesa Agropecuária. Instrução normativa conjunta $\mathrm{n}^{\mathrm{o}} 1$, de 10 de setembro de 2002.

MARI, M., LEONI, O., IORI, R. \& CEMBALI, T. Antifungal vapourphase activity of allyl-isothiocyanate against Penicillium expansum on pears. Plant Pathology 51:231-236. 2002.

MAWAR, R.,S. \& LODHA, S.K. Brassica amendments and summer irrigation for control of Macrophomina phaseolina and Fusarium oxysporum f. sp. cumuni in hot arid regions. Phytopathologia Mediterranea 41:45-54. 2002.

NIELSEN, P.V. \& RIOS, R. Inhibition of fungal growth on bread by volatile components from spices and herbs, and the possible application in active packaging, with special emphasis on mustard essential oil. International Journal of Food Microbiology 60:219229. 2000.

OLIVIER, C., VAUGHN, S.F., MIZUBUTI, E.S.G. \& LORIA, R. Variation in allyl isothiocyanate production within Brassica species and correlation with fungicidal activity. Journal of Chemical Ecology 25:2687-2701. 1999. 